\title{
Investigating the determinants of cassava domestic supply in the Philippines
}

\author{
Rhena Jane M. Soria' and Lemuel S. Preciados ${ }^{1 *}$
}

\begin{abstract}
Cassava is a significant crop in the Philippines because of its many uses and increasing demand from feed milling industries. However, the supply for this crop in the country, compared to other ASEAN countries, remains low and relatively less competitive. There are studies suggesting the need to review factors affecting agricultural supply in the Philippines to support policy initiatives, but only a few studies were conducted specifically targeting the cassava subsector. This study tried to address these gaps. Using time-series regression analysis, this study measured the extent of the effects of the price, area, agricultural R\&D expenditure, tariff rate, and weather occurrences. Results from this study suggest that farm gate price as well as area, agricultural research and development spending, and tariff rate significantly determine supply. In contrast, extreme weather occurrences such as El Niño and La Niña have negative but insignificant effect on supply. In addition, this study has also proven that the identified determinants have long run relationship with cassava domestic supply, which suggests that cassava supply cannot readily adjust to changes in these determinants. These results provide insights into how each variable would affect supply, which have certain implications to policy such as the adoption of specific price policy intervention like price support schemes that safeguard farmers' income against price fluctuations.
\end{abstract}

Keywords: time series analysis, short run, long run, supply response

\section{INTRODUCTION}

Manihot esculenta also known as cassava or manioc is a starchy root and tuber crop that contains $24 \%$ starch (Food and Agricultural [FAO] 2000, International Fund for Agricultural Development [IFAD] 2000). Cassava is locally known as kamote'ng kahoy, balanghoy or balinghoy in the Philippines. It is one of the major root crops in the country. Cassava in the country has three uses: as food, dried chips for feed and starch. It is also a potential alternative of alcohol production for liquor (Bacusmo

'Department of Economics, Visayas State University, Visca, Baybay City, Leyte.

\footnotetext{
* Corresponding Author. Address: Department of Economics, Visayas State University, Visca, Baybay City, Leyte, Philippines; Email: lemuel.preciados@vsu.edu.ph DOI: $10.32945 /$ atr4028.2018
} 
2001). According to De Leon (2011) cassava is regarded as one of the cheapest sources among the major starch-based crops for ethanol production. In 2015, $83.98 \%$ of the country's cassava output was used for manufacturing, $6 \%$ for feed and $10.02 \%$ for disposable consumption (CountryStat Philippines 2017). Cassava is chiefly utilized in the industry as starch and its byproducts serves as inputs for food processing and non-food processing. These inputs for food processing and non-food processing are used as adhesives in paper, plywood, and cardboard. The dried cassava chips as one of the byproducts are used as animal feed which serves as the second industrial outlet next to starch (Roa 1990). Cassava is regarded as a subsistence crop having growing evidence of being a cash-earner for most producers and its output market share usually exceeds the cereals' (FAO \& IFAD 2000), which implies that it is favorable as cash crop. It is regarded as the "poor man's crop" since it is tolerant to abiotic stresses and can survive with any types of soil (Bacusmo 2001, Calderon \& Elazegui 2003). In fact it served as a food security crop in Asia due to El Niño and La Niña events in 1997 and 1998 (FAO \& IFAD 2000).

Cassava as an agriculture crop depends on the factors such as crop area, labor, capital, cost, domestic and world prices, technology, fertilizer use, trade policies, and other external factors such as weather condition, thus this research wants to explain the variations in cassava domestic supply over the years. Determinants of supply (technology, production cost, number of sellers, prices of other goods, price expectations, policies, taxes and subsidies) can either increase or decrease the production of the good, but the factors affecting production cannot be solely explained by the abovementioned determinants, for supply can be also influenced by external factors such as extreme weather events. In addition, this study categorized the factors that can affect the domestic supply of cassava into internal factors and external factors. Internal factors for those that can be controlled by the domestic market or within the producers' control and is further subdivided into direct and indirect factors. The external factors are those factors which can't be controlled by the domestic market or the producers (ie, weather). Characteristically, roots and tuber crops production increases with the planted area since its growth merely depends on the space underground, thus crop area is essential in the analysis. The price is based on the law of supply that as "price increases quantity supplied also increases." Farmgate price is used since it is the price in which the primary producers or farmers customarily responds to. Extreme weather disturbances is a usual dilemma particularly on the farmers, these extreme factors affects output negatively moreover could bring high costs to them. Agricultural policies such as agricultural tariffs and import regulations may hinder or induce production thus affecting domestic supply. Also, support to agriculture like subsidies may encourage producers to cultivate particular crops which may alter supply.

Identifying the determinants for aggregate agricultural production is widely studied in the field of agricultural economics for it uncovers the different factors that affect agricultural production (Hussain \& Ishfaq 1997, Kudaligama \& Yanagida 2010, Mehdi \& Reza 2011, Mubarik \& Warsi 2015, Raza \& Siddiqui 2014, Suphannachart \& Warr 2010). Determinants of aggregate agricultural production is not exclusively studied, in fact determinants of sub-sectoral agricultural production (Suphannachart \& Warr 2010) and of agricultural crop-specific production (Backman \& Nyairo 2009, Blanc 2013, Canlas \& Cruz 2004, Poramacom et al 2013, Valerio 2014) were also empirically studied. Literatures vis-à-vis determinants of 
agricultural production generally varies in the methods applied such as on modeling and econometric techniques. For time series analysis, unit root test, cointegration approach and error correction model is conventionally used (Blanc 2013, Poramacom et al 2013, Raza \& Siddiqui 2014).

Impacts of climate change or weather disturbances on crop supply has been analyzed by a number of studies (Canlas \& Cruz 2004, Backman \& Nyairo 2009, Blanc 2013). In the study of Blanc (2013), climate change is assessed in terms of cumulative precipitation and average temperature while Backman and Nyairo (2009) evaluated climate change in terms of reviewing related literatures nonetheless both derived to an inference that climate change does significantly affect crop production negatively. Canlas and Cruz (2004) measured climatic factors in terms of El Niño Southern Oscillation (ENSO) events for which their results also confirmed that changing weather affects crop supply significantly, thus implying that climate change plays a critical role in agricultural productivity. Knowledge on the determinants of production or supply plays an important role to producers since it helps them decide on the best combination of inputs and be more vigilant on some external factors that they cannot prevent (eg, weather, policies). These empirical studies are very helpful especially in identifying the factors that can significantly improve agricultural output.

This study aimed to measure the extent of the effects of the internal and external factors on the domestic supply of cassava in the Philippines. Specifically, it aimed to analyse the effect of price changes on the supply of cassava, determine the effect of the factors affecting supply of cassava other than price, examine the short run and long run association between cassava domestic supply and its determinants, and to draw policy implications and provide insights for the improvement of the cassava sub-sector in the Philippines.

\section{MATERIALS AND METHODS}

The study categorized the hypothesized factors that affect the domestic supply of cassava into internal and external factors. The internal factors are for factors that can be controlled by the domestic market or within the producers' control. It is further subdivided into direct and indirect factors. Direct factors are factors that are basically involved in the determination of production, while indirect factors are secondary factors that can indirectly influence supply. The external factors refers to the factors that cannot be controlled by any man's power, usually unforeseen or unpredictable (ie, weather disturbances). Figure 1 shows the conceptual framework of the study. 
Investigating the determinants of cassava

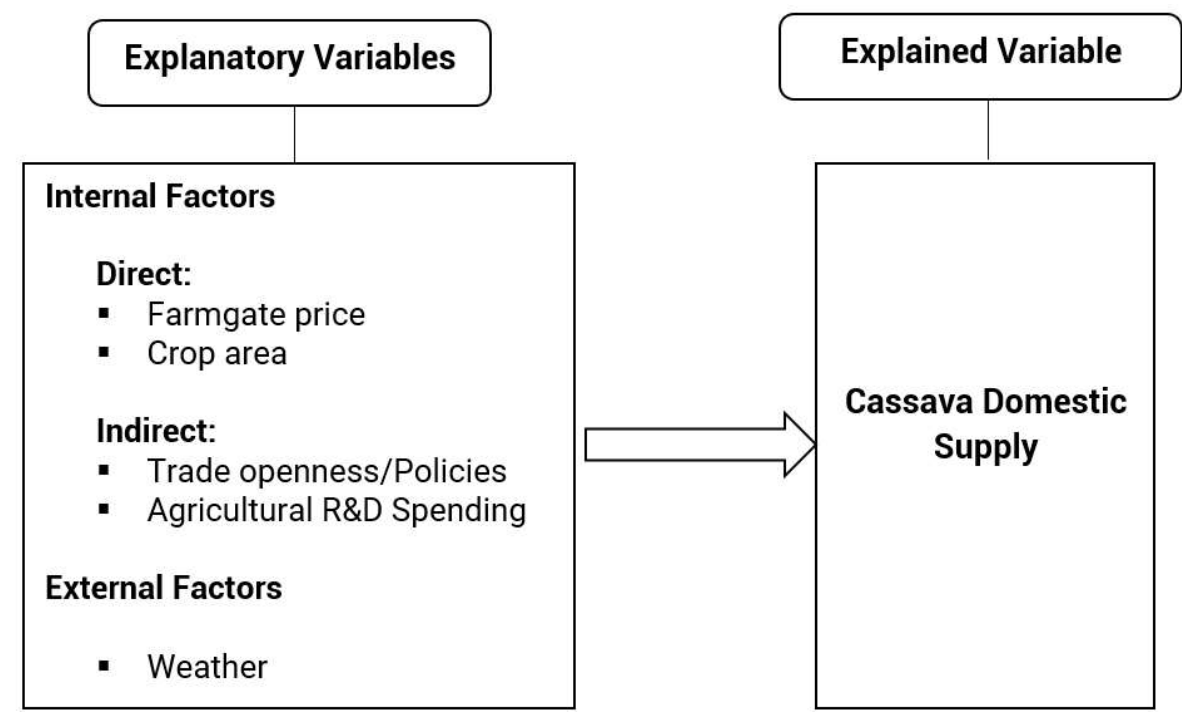

Figure 1. A diagram showing the factors affecting cassava domestic supply

\section{Data Selection and Sources}

The study used annual time series data for all variables from 1985-2015 consisting of 31 observations. "Freer" international trade agreements participated by Philippines initially started in 1990; 1990 for the ASEAN Free Trade Area (AFTA) agreement and 1995 for the General Agreement on Tariffs and Trade-Uruguay Round (GATT-UR). The study included data of the previous years before the trade agreements' implementation so to evaluate the effect of freer trade on the country's cassava supply. Data for the selected variables were gathered from secondary sources and were subjected to further estimations to derive reliable measurements because of data insufficiency (Table 1).

Table 1. Summary of the time series data from 1985-2015 and their sources

\begin{tabular}{llcc}
\hline \multicolumn{1}{c}{ Variables } & \multicolumn{1}{c}{ Definition } & Unit & Source \\
\hline $\begin{array}{l}\text { Dependent Variable } \\
\text { Domestic Supply }\end{array}$ & $\begin{array}{l}\text { Crop harvest per year } \\
\text { Independent Variables }\end{array}$ & 1,000 tons & FAOSTAT \\
Farmgate price & $\begin{array}{l}\text { Average price of the } \\
\text { cassava at farmgate } \\
\text { level Pesos/kg }\end{array}$ & $\begin{array}{l}\text { PSA- Countrystat database, } \\
\text { De Jesus et al (1992) }\end{array}$ \\
Average Harvested area \\
of cassava & 1,000 ha & \\
\hline
\end{tabular}


Table 1. Continuation

\begin{tabular}{|c|c|c|c|}
\hline Variables & Definition & Unit & Source \\
\hline Tariff & $\begin{array}{l}\text { Cassava starch Tariff } \\
\text { rates }\end{array}$ & Percent & $\begin{array}{l}\text { Cabanilla (1988), Gabunada } \\
\text { \& Roa (2003), WITS-WTO } \\
\text { database }\end{array}$ \\
\hline $\begin{array}{l}\text { Agricultural R\&D } \\
\text { expenditure }\end{array}$ & $\begin{array}{l}\text { Annual public spending } \\
\text { for agricultural R\&D }\end{array}$ & $\begin{array}{l}\text { Million } \\
\text { pesos }\end{array}$ & $\begin{array}{l}\text { Intal and Power (1991litera), } \\
\text { Buendia et al (2007), } \\
\text { Department of Agriculture- } \\
\text { Budget Division }\end{array}$ \\
\hline Weather variable & $\begin{array}{l}\text { Dummy variables for El } \\
\text { Niño and La Niña } \\
\text { occurrences }\end{array}$ & & $\begin{array}{l}\text { (Climate Prediction Center, } \\
\text { n.d.) }\end{array}$ \\
\hline Price of related good & $\begin{array}{l}\text { Average farmgate price } \\
\text { of corn at farmgate level }\end{array}$ & Pesos/kg & $\begin{array}{l}\text { PSA- Countrystat database, } \\
\text { De Jesus et al (1992) }\end{array}$ \\
\hline
\end{tabular}

\section{Specification of the Dependent Variable}

\section{Production}

The study used the data for annual production of cassava as the dependent variable in metric tons because it is a direct measurement of crop harvest (basically domestic supply).

\section{Selection of Explanatory Variables and Hypotheses}

\section{Farmgate price}

Prices determine the behavior of producers towards producing and selling. If farmgate prices increased farmers would respond to it positively, thus increasing production. The study used farmgate prices as the domestic price instead of wholesale or retail prices because farmgate prices closely indicate a farmer's behavior towards selling. Farmgate price was used as it directly affects the supply of cassava in the domestic market. Other price (international market price) may also affect supply indirectly, but was not considered in this study.

\section{Crop area}

A larger planting area for crops indicates higher production, thus an increase in crop area increases production, all other things equal. 
Investigating the determinants of cassava

\section{Agriculture r\&d expenditure}

Government intervention through R\&D could help primary producers particularly the farmers who want to increase their crop yields. Cassava researches usually were focused more on formulating high-yielding crop varieties or technology-wise method of production (PhilRootcrops 2017), thus government investing on these stakeholders could increase or sustain total crop production of the country. Subsidies such as through agricultural R\&D spending functions as an innovation for farmers or producers thus increasing production, all other things equal.

\section{Tariff}

The baseline for trade openness is the ASEAN Free Trade Area (AFTA) or AFTACEPT (Common Effective Preferential Tariff) agreement since the country's cassava imports is chiefly from the neighboring southeastern countries. An increase in the protection for the domestic market benefits the domestic producers, however trade liberalization-simply reduction or removal of trade barriers - may discourage farmers to produce more especially if the country is a net-importer of the good, because freer trade indicates lower import prices thus increasing purchase of imports relative to domestic prices. Therefore, trade liberalization may cause decrease in domestic supply of the good relative to import prices. The cassava starch tariff rate was used since the top industrial use and import of cassava and products in the country is cassava starch.

\section{Weather}

Weather affects the harvest of farmers. Heavy rainfall or typhoons that cause floods and waterlogged on lands or El Niño that causes damage to crops or stagnant growth of crops due to lack of moisture, decreases supply of the crop. The Oceanic Niño Index (ONI) is the standard that National Oceanic and Atmospheric Administration (NOAA) used for identifying El Niño (warm) and La Niña (cool) events in the tropical Pacific (Null 2017). The study used dummy variables for El Niño Southern Oscillation (ENSO) warm events (El Niño) and cool events (La Niña) based on Oceanic Niño Index (ONI). Events are defined as five consecutive overlapping 3-month periods at or above the $+0.5^{\circ}$ anomaly for warm (EI Niño) events and at or below the -0.5 anomaly for cold (La Niña) events (Null 2017). The weather dummies were lagged because the effect of these disturbances could be later since cassava harvest time will still be after 8-10 months.

\section{Price of related goods}

Changes in the price of related goods can affect the supply of the good. The farmgate price of corn was used as the proxy variable for these other good. Corn and cassava are the closest substitutes in terms of industrial uses such as starch, animal feed material and ethanol production. Cassava not only acts as substitute of corn but also as a complement because in times of pest diseases or natural calamities, cassava is utilized as a backup good since it is a rootcrop and is more 
resilient to abiotic strains. Hence, an increase in the price of corn may increase or decrease supply of cassava if the crop serves as complement or substitute respectively. The lagged value of the corn farmgate price was used to match the assumption on the effect of cassava farmgate price to cassava supply.

\section{Econometric model}

This study aimed to determine and estimate the effect of the factors affecting supply of cassava. Using the identified variables covered in previous studies from factors that affect agricultural production (Hussain \& Ishfaq 1997, Kudaligama \& Yanagida 2010, Mehdi \& Reza 2011, Mubarik \& Warsi 2015, Raza \& Siddiqui 2014, Suphannachart \& Warr 2010) and from the studies on the determinants of agricultural-crop specific production (Backman \& Nyairo 2009, Blanc 2013, Canlas \& Cruz 2004, Poramacom et al 2013, Valerio 2014), this current study conceptualized the econometric model for investigating determinants specific for cassava. The long-run model used in this study is analyzed as follows:

Domestic supply $=f$ (area, farmgate price, weather, tariff rate, agricultural R\&D spending, price of related good)

The econometric model is expressed as follows:

$$
\begin{aligned}
\log \text { supply }_{t}= & \beta_{0}+\beta_{1} \text { area }_{t}+\beta_{2} \text { fgprice }_{t-1}+\beta_{3} \text { agrd }_{t-1}+\beta_{4} \text { priceog }_{t-1} \\
& +\beta_{5} \text { tariff }_{t}+\beta_{6} \text { elniño }_{t-1}+\beta_{7} \text { laniñ }_{t-1}+\varepsilon_{t}
\end{aligned}
$$

\begin{tabular}{|c|c|c|}
\hline $\mathrm{t}$ & $=$ & $1985,1986,1987, \ldots, 2015$ \\
\hline$d s u p p l y_{t}$ & $=$ & domestic production ( 1,000 tons $)$ \\
\hline area $_{t}$ & $=$ & planted/ harvested area $(1,000 \mathrm{ha})$ \\
\hline tarrif $_{t}$ & $=$ & cassava starch tariff rate $(\%)$ \\
\hline fgprice $_{t-1}$ & $=$ & farmgate price in the previous year (pesos $/ \mathrm{kg}$ ) \\
\hline $\operatorname{agrd}_{t-1}$ & $=$ & $\begin{array}{l}\text { agricultural R\&D expenditure in the previous } \\
\text { year(million pesos) }\end{array}$ \\
\hline priceog $_{t-1}$ & $=$ & $\begin{array}{l}\text { farmgate price of corn in the previous year } \\
\text { (pesos } / \mathrm{kg} \text { ) }\end{array}$ \\
\hline$e \operatorname{lniño} o_{t-1}$ & $=$ & $\begin{array}{l}\text { lagged ENSO warm events or with El Niño }(1= \\
\text { with } 5 \text { or more consecutive overlapping } 3 \text {-month } \\
\text { periods at or above the }+0.5^{\circ} \text { anomaly; } 0= \\
\text { otherwise) }\end{array}$ \\
\hline $\operatorname{laniña}_{t-1}$ & $=$ & $\begin{array}{l}\text { lagged ENSO cold events or with La Niña }(1= \\
\text { with } 5 \text { or more consecutive overlapping } 3 \text {-month } \\
\text { periods at or below the }-0.5^{\circ} \text { anomaly; } 0= \\
\text { otherwise) }\end{array}$ \\
\hline & $=$ & rrorterm \\
\hline
\end{tabular}

Where: 
Investigating the determinants of cassava

\section{Data analysis}

After estimating the long run dynamics of the model through Ordinary Least Squares (OLS), the model then underwent various diagnostic tests to assure the validity of the model. Time series analysis requires a step by step process that prevents you from proceeding to other steps without satisfying the preceding one. The steps are 1) the unit root test to test for stationarity of the time series data, 2) the cointegration test to test for long run relationship, and 3 ) the error correction model to test for the short run effects.

\section{Unit root test}

A unit root is a feature of some stochastic processes that can cause problems in statistical inference involving time series models. A unit root test is used to determine if trending data should be first di『erenced or regressed on deterministic functions of time to render the data stationary. Moreover, economic and finance theory often suggests the existence of long-run equilibrium relationships among nonstationary time series variables. If these variables are I (1) (ie, first-difference stationary), then cointegration techniques can be used to model these long-run relations. Estimates from nonstationary variable may generate a spurious regression unless they are cointegrated, hence pre-testing for unit roots is often a first step in the cointegration modeling. The study will use Augmented Dickey and Fuller (ADF) test as the stationarity test for all variables. The null hvpothesis of the test is there is unit root or time series is non-stationary; $H_{0}: \delta=0$, whereas the alternative hypothesis indicates no unit root or time series is stationary; $\boldsymbol{H}_{\boldsymbol{a}}: \boldsymbol{\delta}<\mathbf{0}$. There were two auxiliary regressions considered with ADF test; with intercept and trend (2) and with intercept only (3).

$$
\begin{aligned}
& \Delta Z_{t}=\beta_{1}+\beta_{2} t+\delta_{t-1}+\sum_{i=1}^{n} \alpha_{t} \Delta Z_{t-1}+\varepsilon_{t} \\
& \Delta Z_{t}=\beta_{1}+\delta_{t-1}+\sum_{i=1}^{n} \alpha_{t} \Delta Z_{t-1}+\varepsilon_{t}
\end{aligned}
$$

\section{Cointegration Analysis}

The fact that non-stationary processes can have linear combinations that are stationary was called cointegration by Engle and Granger (1987). The concept of cointegration method is to test the long run relationship between the variables. The study uses the ADF test to test if the residuals has presence of unit root at levels. If the test rejects the null hypothesis of non-stationarity, it means that there is a long run relationship or long-term equilibrium among the variables. A Johansen cointegration test was also applied in the study; the method assumes that all the variables are non-stationary at levels but when first-differenced suffices stationarity and provides the number of cointegrating equations in a model. Johansen test also serves as preliminary estimation before running a Vector Error Correction Model (VECM) if the model is proven to be cointegrated; VECM is a method used in estimating short run effects. Equation 4 shows the calculation for the residual of the postulated model. 


$$
\begin{aligned}
\varepsilon_{t}=\log d \text { supp } & y_{t} \\
& -\left(\beta_{0}+\beta_{1} \text { area }_{t}+\beta_{2} \text { fgprice }_{t-1}+\beta_{3} \text { agrd }_{t-1}+\beta_{4} \text { priceog }_{t-1}\right. \\
& \left.+\beta_{5} \text { tariff }_{t}+\beta_{6} \text { elniño }_{t-1}+\beta_{7} \text { laniñ }_{t-1}\right)
\end{aligned}
$$

\section{Error Correction model (ECM)}

The ECM addresses the problem of spurious regression that can be present when using non stationary time series and it enables separate estimation for short and long run elasticities (Blanc 2013). If proven that the model is cointegrated, the analysis can then proceed to estimating the short run dynamics of the variables using the VECM. The error correction term is derived using the number of cointegrated equations, if the variables are not cointegrated then the model will be analyzed in first-difference level through the OLS method and the error correction term will be disregarded (Seriño 2012).

\section{RESULTS AND DISCUSSION}

\section{Descriptive Statistics}

Table 2 shows the 10-year average of the variables that were examined in this study. The secondary data suggest that overtime there is generally an increasing trend for the domestic supply of cassava in the Philippines. With highest production recorded in year 2015 which reached 2.71 million tons. It could also be observed that domestic supply before year 1995 appeared to be larger compared to the supply after 1995. It is important to note that the establishment of World Trade Organization (WTO) was on the January 1,1995 , and data suggest that cassava production performance of the country before 1995 was performing better in comparison when the Philippines was engaged in to greater trade openness with other countries. This changes in the performance may be attributed by the reduced barriers to trade (tariff rate) which is also being examined in this study as one determinants explaining variations of cassava domestic supply. In lieu to this, this result has shown consistency with the data from the changes of tariff rate overtime. Table 2 shows that the 10-year average of tariff rate for cassava before 1995 was $45 \%$ indicating higher trade restrictions and better protection for domestic producers. However, it can be seen that this rate has decreased from $45 \%$ to $8.10 \%$ after 1995 (10-average from 1996-2005), which likely has resulted to the lesser domestic supply of cassava in the country. Other factors that may explain the variation of supply is the area, farm gate price, agricultural spending, price and other goods related to cassava. The data show that these variables have been also generally increasing overtime, which could also explain the generally increasing trend of cassava domestic supply. However, these trend analysis or descriptive statistics do not explicitly determine the direct relationship among the examined variables, therefore a time-series regression analysis was done in this study to capture the causal link of the identified explanatory variables with the explained variable-the cassava domestic supply. 
Investigating the determinants of cassava

Table2. Descriptive statistics of the variables

\begin{tabular}{lccc}
\hline \multirow{2}{*}{ Variables } & \multicolumn{3}{c}{ Average (10-year) } \\
\cline { 2 - 4 } & $1986-1995$ & $1996-2005$ & $2006-2015$ \\
\hline Domestic Supply & 1831.27 & 1747.67 & 2176.03 \\
Area & 212.99 & 214.35 & 215.48 \\
Farmgate Price & 1.77 & 3.64 & 5.98 \\
Agricultural R\&D Spending & 469.82 & 846.98 & 1628.20 \\
Price of other good & 4.19 & 6.76 & 11.70 \\
Tariff rate & 45.00 & 8.10 & 2.00 \\
\hline
\end{tabular}

\section{Stationarity Test}

Unit root tests can be used to determine if trending data should be first differenced or regressed on deterministic functions of time to render the data stationary. Moreover, economic and finance theory often suggests the existence of long-run equilibrium relationships among nonstationary time series variables. If these variables are I (1), then cointegration techniques can be used to model these long-run relations. Estimates from nonstationary variable may generate a spurious regression unless they are cointegrated. Hence, pre-testing for unit roots is often a first step in the cointegration modeling. Table 3 shows the results for unit root test; all the variables are non-stationary at levels both in intercept only and with intercept and trend except for the weather dummy variables, but when first-differenced all the non-stationary variables at levels were stationary both in intercept only and with intercept and trend at one percent level of significance, thus stationarity of the data is attained at first-difference level or I(1), hence we can proceed with cointegration techniques to attest if there is long-run relationship among the variables.

Table 3. Unit root test for stationarity using ADF Test

\begin{tabular}{|c|c|c|c|c|}
\hline \multirow[b]{2}{*}{ Variables } & \multicolumn{2}{|c|}{ Level } & \multicolumn{2}{|c|}{ First-Difference } \\
\hline & Intercept & $\begin{array}{l}\text { Intercept and } \\
\text { Trend }\end{array}$ & Intercept & $\begin{array}{l}\text { Intercept and } \\
\text { Trend }\end{array}$ \\
\hline Domestic Supply & 1.944 & 0.834 & $-4.280 * \star \star$ & $-5.070 \star \star \star$ \\
\hline Area & -2.483 & -2.453 & $-6.791 * \star \star$ & $-6.643^{\star \star \star}$ \\
\hline Farmgate Price & -1.09 & -2.533 & $-4.571 * \star \star$ & 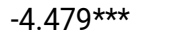 \\
\hline Agric R\&D Spending & 1.764 & 0.236 & $-5.276^{\star \star \star}$ & 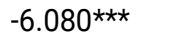 \\
\hline Price of related good & -0.365 & -2.723 & $-6.966 * \star \star$ & $-6.811 * \star \star$ \\
\hline Tariff & $-5.466^{\star \star \star}$ & $-5.403^{\star \star \star}$ & - & - \\
\hline ELNIÑO & 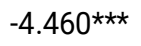 & 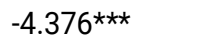 & - & - \\
\hline LANIÑA & $-2.689 *$ & 1.92 & $-6.327 * \star \star$ & $-6.274^{\star \star \star}$ \\
\hline
\end{tabular}

Note: $\operatorname{lag}(s)=0$

$\star \star \star \star p<0.01, * \star p<0.05, * p<0.1$ 


\section{Cointegration Test}

The fact that non-stationary processes can have linear combinations that are stationary was called cointegration by Engle and Granger (1987). Since most of the variables are non-stationary at levels but first-difference stationary, thus we apply cointegration methods and further address the problem of spurious regression which can be present in testing non-stationary series. The concept of cointegration method is to test the long run relationship between the variables. The study applied ADF test on the residuals of the model to test presence of unit roots, the results in Table 4 showed that the model is stationary at $1 \%$ level of significance both in intercept only and with intercept and trend, thus indicating that the variables are cointegrated in I (1) or order 1 . The study also applied Johansen cointegration test for non-stationary variables at levels but stationary at first-differenced. Table 5 shows that there are three cointegrated equations or in other words there exists a long run relationship among the variables. Since the results of both test shows that there exists a long run relationship among variables, hence we can proceed with the next analysis of determining its short run dynamics through VECM.

Table 4. Cointegration test using ADF Test for stationarity of residuals at levels

\begin{tabular}{llc}
\hline \multirow{2}{*}{ Variable } & \multicolumn{2}{c}{ Level } \\
\cline { 2 - 3 } & Intercept & Intercept and Trend \\
\hline ADF Test Statistic & $-5.103^{\star \star \star}$ & $-5013^{\star \star \star}$ \\
\hline
\end{tabular}

Note: $\operatorname{lag}(\mathrm{s})=0$

Table 5. Johansen Cointegration Test for non-stationary variables at levels

\begin{tabular}{|c|c|c|c|c|c|c|}
\hline \multirow{2}{*}{ Statistic } & Ho: $\quad r=0$ & $r=1$ & $r=2$ & $r=3$ & $r=4$ & $r=5$ \\
\hline & $\mathrm{Ha}: \quad r \geq 1$ & $r \geq 2$ & $r \geq 3$ & $r \geq 4$ & $r \geq 5$ & $r \geq 6$ \\
\hline Trace Statistic & $148.18^{\star}$ & $95.05^{\star}$ & $55.70 *$ & 22.34 ** & 3.23 & 0.30 \\
\hline$p$-value & 0.0000 & 0.0001 & 0.0077 & 0.2797 & .0 .9552 & 0.5841 \\
\hline Max Statistic & $53.13^{\star}$ & $39.35^{\star}$ & $33.36^{\star}$ & $19.11^{\star \star *}$ & 2.94 & 0.30 \\
\hline$p$-value & 0.0010 & 0.0101 & 0.0081 & 0.0937 & 0.9510 & 0.5841 \\
\hline
\end{tabular}

Note: $r$ is the number of cointegrating vectors. The sign $(*)$ indicates the rejection and $(* *)$ for the acceptance of the null hypothesis at $5 \%$ level of significance. Maximum lag(s) $=2$

\section{Regression Results}

\section{A. Long run estimates}

Table 6 shows the long run dynamics of the variables which was estimated through Ordinary Least Squares (OLS). All the identified determinants explains $95.54 \%$ of the variations in cassava domestic supply and is highly significant at $1 \%$ level of significance. As hypothesized; area, farmgate price, agricultural R\&D spending, price of related good and tariff has positive association with cassava supply and is highly significant at $1 \%$ level of significance, while the weather factors has negative association with cassava supply but insignificant. 
Investigating the determinants of cassava

Table 6. Long-run estimates using OLS

\begin{tabular}{ll}
\hline Variables & Estimates \\
\hline Area & $0.0068^{\star \star \star}$ \\
Farmgateprice $_{t-1}$ & -0.00094 \\
& $0.0476^{\star \star \star}$ \\
Agricultural R\&D spending $t_{t-1}$ & -0.01432 \\
& $0.00005^{\star \star \star}$ \\
Price of other good & -0.00002 \\
& $0.0184^{\star \star}$ \\
Tariff & -0.00733 \\
& $0.0056^{\star \star \star}$ \\
El Niño & -0.0006 \\
& -0.0129 \\
La Niña & \\
& -0.0138 \\
Constant & -0.0074 \\
& -0.0127 \\
R-squared & $5.6411^{\star \star \star}$ \\
F-Statistics & -0.2032 \\
\end{tabular}

Note: Standard errors in parentheses

$\star \star \star x<0.01, * \star p<0.05, \star p<0.1$

\section{Direct Factors Affecting Cassava's Domestic Supply}

\section{Area}

The estimate of the coefficient for area suggests that when area increases by one thousand hectares is likely to lead to a $0.68 \%$ increase in the supply of cassava. This significant positive association between supply and area corresponds to our expectation as most studies indicated a clear association between supply and area harvested. Similarly, cropped area exhibited positive correlation with agricultural production (Canlas \& Cruz 2004, Hussain \& Ishfaq 1997, Mehdi \& Reza 2011, Poramacom et al 2013, Valerio 2014).

\section{Farmgate price}

Farmgate price significantly influences cassava supply which is consistent with the law of supply. The estimated coefficient indicates that the one period lag of farmgate price is statistically significant at $1 \%$ level meaning for every peso per kilogram increase in cassava's farmgate price in the previous year will increase its current supply by $4.76 \%$. This significant association between farmgate price and domestic supply corresponds to our expectation for previous year's farmgate price would still affect current supply since cassava harvest time will still be after 8-10 months. Likewise, farmgate prices of the previous year showed positive association with crop-specific production (Canlas \& Cruz 2004, Poramacom et al 2013). 
Soria \& Preciados

\section{Indirect Factors Affecting Cassava's Domestic Supply}

\section{Price of related crop}

The estimate for the farmgate price of corn suggests that in its every peso increase, it helps increase cassava supply by $1.84 \%$. This significant positive association between supply and price of corn corresponds to our assumption that cassava serves not only as substitute of corn but also as its complement good, hence result indicates that increase in price of corn would also increase cassava supply because in times of pest diseases or natural calamities, cassava is utilized as a backup good since it is a rootcrop and is more resilient to abiotic strains.

\section{Tariff rate}

Another factor that indirectly affects cassava supply is the cassava starch tariff rate. A one unit increase in tariff rate will increase cassava supply by $0.56 \%$, therefore an increase in the trade protection (ie, tariff rate) for this crop rises supply. This result may also imply that lesser trade barriers can decrease cassava supply, because there would be more foreign sellers in the domestic market. This greater trade openness as indicated with reduced tariff rate for cassava starch would likely displace some local producers because they are not able to compete with the relatively lower import prices, all things being equal. Accordingly, tariff rate charges or any trade barriers protects the local producers and the domestic market from massive inflow of foreign products so a reduction in tariff means lower import price thus affecting domestic price negatively.

\section{Agricultural R\&D Expenditure}

Spending for agricultural research and development is also a factor contributing to the increase in production of cassava in the country. A million increase in the previous year's agricultural R\&D expenditure increases cassava supply by $0.005 \%$, the figure shows minimal increase in the supply since the expenditure is for the aggregate agriculture. Nonetheless it still implies that increasing agricultural support in research and development particularly for cassava will help improve the supply of the crop. Most of the R\&D investments on cassava goes to its varietal improvement (PhilRootcrops 2017) including breeding of high-yielding varieties which can significantly increase yield.

\section{External Factors Affecting Cassava's Domestic Supply}

\section{Weather}

External or exogenous factors like the weather dummy variables (El Niño and La Niña) have a negative association with cassava supply since extreme weather events naturally damage crop harvest. An occurrence of El Niño decreases supply by $1.29 \%$, while an occurrence of La Niña decreases supply by $0.74 \%$. However, the effect of these factors is insignificant hence supporting studies that showed cassava crop as tolerant to abiotic stresses. 
Investigating the determinants of cassava

\section{B. Short run estimates}

The error correction term measures the speed of adjustment at which a dependent variable returns to equilibrium after a change in other variables. The idea behind the error correction model is that even if variables has long run equilibrium relationship, disequilibrium in the short run is possible (Seriño 2012). The rule of thumb of the VECM technique is when error correction term is negative and significant, it attests that there exists short-run dynamics that runs from the independent variables towards the dependent variable. After conducting cointegration test we have proven that the variables move together in the long run, hence we can proceed to estimating its short run dynamics using the Vector Error Correction Model (VECM). Table 7 displays the short run estimates of the variables at lags 1 and 2, however result shows that jointly the identified determinants and cassava supply didn't attain equilibrium in the short run since the error correction term is negative but insignificant implying that cassava supply cannot readily adjust with changes in the determinants probably because cropping of cassava takes longer time than that of other crops and it also corresponds to the theory of determinants of elasticity of supply that time is the main determinant of elasticity of supply, since it takes amount of time that a producer can respond to a given change on the identified factors in the model.

Table 7. Short run estimates using VECM

\begin{tabular}{lllll}
\hline Variables & Coefficient & Std. Error & t-Statistic & Prob. \\
\hline ECT(-1) & -0.4710 & 0.9747 & -0.4832 & 0.6393 \\
logdsupply $(-1)$ & -0.1072 & 0.6333 & -0.1693 & 0.8689 \\
logdsupply (-2) & 0.0191 & 0.6650 & 0.0287 & 0.9777 \\
area $(-1)$ & 0.0055 & 0.0048 & 1.1380 & 0.2816 \\
area $(-2)$ & 0.0023 & 0.0045 & 0.5242 & 0.6116 \\
fgprice $(-1)$ & -0.0518 & 0.0599 & -0.8646 & 0.4075 \\
fgprice $(-2)$ & -0.0299 & 0.0453 & -0.6604 & 0.5239 \\
agrd $(-1)$ & 0.0000 & 0.0001 & -0.4398 & 0.6694 \\
agrd $(-2)$ & 0.0001 & 0.0001 & 0.5239 & 0.6118 \\
priceog $(-1)$ & 0.0428 & 0.0385 & 1.1125 & 0.2920 \\
priceog $(-2)$ & 0.0393 & 0.0314 & 1.2503 & 0.2396 \\
tariff $(-1)$ & -0.0066 & 0.0048 & -1.3767 & 0.1986 \\
tariff $(-2)$ & -0.0002 & 0.0024 & -0.1025 & 0.9204 \\
elniño & -0.0179 & 0.0248 & -0.7205 & 0.4877 \\
laniña & 0.0412 & 0.0364 & 1.1344 & 0.2831 \\
Constant & -0.0207 & 0.0438 & -0.4728 & 0.6465 \\
R-squared & 0.6621 & & & \\
\hline
\end{tabular}

$\star \star \star p<0.01, * \star p<0.05, * p<0.1$

Note: $(-1)$ means one year lag, $(-2)$ means two years lag

Variables: ECT - Error Correction Term, logdsupply - logarithmic value of domestic supply, area planted area, fgprice - farmgate price, agrd - agricultural research and development spending, priceog - price of other good (corn), tariff - cassava tariff rate, elniño - ENSO warm events, laniña - ENSO cold events. 


\section{CONLUSIONS AND POLICY IMPLICATIONS}

This study determined the factors that affect cassava's domestic supply in the Philippines. The findings showed that direct factors like increase in farmgate price and increase in production area positively affect supply of cassava significantly. Other factors like tariff rate, price of related good, and agricultural R\&D spending also positively affect cassava supply. The effects of the factors identified in the model are expected and all coincides with the theory of supply, but it is difficult to measure precisely how much of a given change in supply due to its different determinants. There might be other variables such as non-price variables, institutional factors, and technical change that may also explain increase in supply and productivity, but there is no satisfactory way to measure them. Inclusion of other factors like world market price is also recommended since it could affect domestic supply.

There were five factors determined that are likely to influence cassava's domestic supply. These were farm gate price of cassava, the allocated harvested area for cassava, agricultural R\&D initiatives by the government, price of related crop, and tariff for cassava starch. These determinants are considered supply shifters that cause the increase and decrease of cassava's supply in the country, all things equal. Interestingly, this study also found that cassava is resilient with abiotic stresses and extreme weather conditions indicating the potential of this crop to be the best alternative for rice and corn production during rainy seasons. As regards to the long-run estimates of this study, the results provide insights into how each variable should affect supply. These results have certain implications for policy makers. For instance, evidence of this model suggests that farmers do respond positively to price signals. Therefore, specific price policy could be adopted by the government like price support schemes, which can safeguard farmers' income against price fluctuations. This intervention has been proven effective in other countries like Thailand, which makes their country consistently the number one in cassava production in ASEAN.

\section{REFERENCES}

Albayrak N. 1997. Applying Time Series Analysis to Supply Response and Risk. PhD Thesis, University of Leicester, Department of Economics

Bäckman S and Nyairo N. 2009. Analysis factors affecting supply of agricultural products: market liberalization, agricultural policies, bioenergy policies, population growth,input price development, trade policies and other relevant factors. University of Helsinki, Department of Economics and Management, Finland

Bacusmo JL 2001. Status and Potentials of the Philippines Cassava Industry. 84101. Retrieved July 15, 2016, from http://ciat-library.ciat.cgiar.org/articulos_ ciat/asia/proceedings_workshop_00/84.pdf

Blanc E. 2013. Food crop supply in sub-Saharan Africa and climate change. Journal of Development and Agricultural Economics, 5(9):337-350

Cabanilla LS. 1988. Trends and Prospects for Cassava in the Philippines. International Food Policy Research Institute, Washington, DC

Calderon RP and Elazegui DD. 2003. Tracking Policies and Analyzing their Implications on the Development of Root Crop Starches. University of the Philippines, Institute of Strategic Planning and Policy Studies, Los Baños 
Investigating the determinants of cassava

Canlas FM and Cruz CJ. 2004. Philippine Agricultural Crop Production Cycle: Evidence and Determinants. Thesis, University of the Philippines, School of Economics.Retrievedfromhttp://citeseerx.ist.psu.edu/viewdoc/download?doi $=10.1 .1 .104 .5142 \&$ rep=rep1\&type=pdf

Climate Prediction Center. nd. Retrieved February 2017, from National Oceanic and Atmospheric Administration (NOAA)/ National Weather Service: http://origin.cpc.ncep.noaa.gov/products/analysis_monitoring/ensostuff/ON I_v5.php

Countrystat Philippines. 2016. Retrieved October 2016, from http://countrystat. psa.gov.ph/

De Jesus CC, Librero AR, Mamon CR \& Santos CB. 1992. CGPRT Crops in the Philippines: A Statistical Profile, 1960-1990. Philippine Council for Agriculture, Forestry and Natural Resources Research Development (PCARRD). Regional Coordination Centre for Research and Development of Coarse Grains, Pulses, Roots and Tuber Crops in the Humid Tropics of Asia and the Pacific (CGPRT Centre)

De Leon DR. 2011. Burea of Agricultural Research. Retrieved November 12, 2016, from BAR Research and Development Digest: http://www.bar.gov.ph/index.p hp/digest-home/digest-archives/364-2011-4th-quarter/2043-cassava-the-staplefood-of-the-masses

Engle RF and Granger C. 1987. Co-integration and Error Correction: Representation, Estimation, and Testing. Econometrica, 55(2):251-276

FAOSTAT. 2016. Retrieved August 2016, from http://faostat3.fao.org/: http://faostat3.fao.org/download/FB/FBS/E

Gabunada FM and Roa JR. 2003. Assessment of the Starch Industry. Philippine Root Crop Research and Training Center, Visca, Baybay City, Leyte

Hussain TS and Ishfaq M. 1997. Dynamics of Agricultural Productivity and Poverty in Pakistan. The Lahore Journal of Economics, 3(1)

Intal PJ and Power JH. 1991. An Overview of the Philippine Economy and Agricultural Sector. The Political Economy of Agricultural Pricing Policy, 2:149189

Kudaligama VP and Yanagida J. 2000. A Comparison of Intercountry Agricultural Production Functions: A Frontier Function Approach. Journal of Economic Development, 25(1):57-74

Mehdi S. 2011. Determinants of Agricultural Sector in Developing Countries: The Case of Iran. Annals of Biological Research, 2(6):42-55

Mubarik M and Warsi A. 2015. Determinants of Agricultural Production: A Crosscountry Sensitivity Analysis. South Asian Journal of Management Sciences, 9(2):32-42

PHILROOTCROPS. 2017. January. Retrieved from Phillippine Root Crop Research and Training Center: https://philrootcrops.vsu.edu.ph/

Poramacom N, Ungsuratana A, Ungsuratana P, \& Supavititpattana P. 2013. Cassava Production, Prices and Related Policy in Thailand. American International Journal of Contemporary Research, 3(5):43-51

PSA. 2015. Crops Statistics of the Philippines 2010-2014. Philippine Statistical Authority

Raza J and Siddiqui W. 2014. Determinants of Agricultural Output in Pakistan: A Johansen Co-integration Approach. Academic Research International, 5(4):3046

Roa JR. 1990. A Status Report on Cassava (Philippines). Visayas State University, Philippine Root Crop Research and Training Center, Baybay City, Leyte 
Seriño MN. 2012. Effects of International Remittances on the Philippine Economy: A Cointegration Analysis. De La Salle University Business \& Economics Review, 21(2):47-62

Suphannachart W and Warr P. 2010. Total Factor Productivity in Thai Agriculture: Measurement and Determinants. ARE Working Paper No. 2553/1, Kasetsart University, Department of Agricultural and Resource Economics, Bangkok 